Article

\title{
Drivers behind Residential Electricity Demand Fluctuations Due to COVID-19 Restrictions
}

\author{
Stephen Snow *, Richard Bean, Mashhuda Glencross ${ }^{(D)}$ and Neil Horrocks \\ Centre for Energy Data Innovation, ITEE, University of Queensland, Brisbane 4072, Australia; \\ r.bean1@uq.edu.au (R.B.); m.glencross@uq.edu.au (M.G.); n.horrocks@uq.edu.au (N.H.) \\ * Correspondence: s.snow@uq.edu.au
}

Received: 16 July 2020; Accepted: 21 October 2020; Published: 2 November 2020

check for updates

\begin{abstract}
The COVID-19 pandemic rapidly reoriented the lives of billions of people across the globe toward working, learning, and subsisting from home. This paper examines the consequences of this disruption of electricity use in Australian households. Using high-frequency electricity monitoring from 491 houses and per-circuit monitoring and in-depth interviews with 17 households, the paper (1) compares changes in energy use before and during COVID-19 lockdown, (2) quantifies the key drivers of changes in energy use experienced by households during lockdown, and (3) tracks households' interactions with energy use feedback. The findings identify significant increases in certain aspects of household electricity use directly related to COVID-19, including increased cooking and digital device use. Yet despite the government mandate requiring a large proportion of the population to remain at home, overall energy use among the majority of Queensland households monitored actually decreased during lockdown versus prior, driven primarily by a reduction in air conditioner use during lockdown as the weather cooled. Further, despite significant quantified and self-reported changes in energy use, users who had energy use feedback installed accessed their dashboards less during lockdown than they did prior. The paper discusses these results in the context of statistics on COVID-19 related energy demand fluctuations elsewhere, and the implications for the provision of energy use information to residents during significant disruptions such as lockdown.
\end{abstract}

Keywords: COVID-19; energy; demand; behaviour; energy literacy; household; human-computer interaction

\section{Introduction}

COVID-19 social distancing measures in Australia and across the world have resulted in large sections of the population having to remain at home. In many areas, this change has resulted in a temporary redistribution of electricity demand away from commercial districts and city centres to residential areas [1] and resulted in economic impacts on consumers through higher usage and higher bills [2]. Data from the US, Europe, and India show that power sector activity decreased by $15 \%$ on average during the most restrictive confinement level (covering early-mid April), while residential electricity consumption rose by 5\% [3]. In Australia, overall electricity demand fell by $6.7 \%$ in March, while residential demand increased by $14 \%$ in the state of Victoria [4]. A lack of smart metering in other Australian states makes it difficult to isolate residential demand from total load [5]. Yet despite reporting of these overall trends, there is little first-hand information about the drivers of these changes at the household scale and the relative contribution of different activities and appliances. Most homeowners lack point-of-sale information on their electricity use [6], are billed for electricity only once per quarter [7], and hence lack timely information on how COVID-19 lockdown has affected their electricity use. 
In this paper, we supplement understandings of COVID-19 related changes to state-wide electricity demand with detailed high-frequency household level and circuit level electricity monitoring from 17 households in the state of Queensland that is triangulated with self-reporting of changes to routines, circumstances, and appliance use during COVID-19 lockdown. This level of detail allows us to better isolate the effect of COVID-19 on energy use, relative to changes caused by seasonal variation, and understand the human drivers of these changes. Rather than only reporting what changes to energy use have occurred, as per existing data from the energy sector [4,8], our data allows us to additionally answer how and why these changes have occurred, providing insight into how households have responded to and managed life under lockdown. By including personal accounts of COVID-related changes to household practices, this work builds on previous work which seeks to understand social trends and events as manifest in electricity use patterns [9]. Secondly, we report on the engagement of households with their energy use feedback systems during lockdown. The paper contributes to understanding the potential of feedback to support transitions in consumption patterns and life events.

\section{Background and Hypotheses}

\subsection{Australia's COVID-19 Timeline}

In line with much of Australia, Queensland enacted strict social distancing rules from 20 March 2020 until 11 May 2020. Restrictions began to be gradually relaxed from 11 May when schools opened to Kindergarten, Prep, Grade 11 and 12 students. Yet as of the time of writing (September 2020), certain pubs, clubs, churches, and other large gatherings remain banned and state borders remain closed. Table 1 provides a brief timeline of events related to social distancing measures in the state of Queensland during the study period, where the per-circuit monitoring and self-reported data is gathered. To assist with utility bills during lockdown, the Queensland Government provided a utility bill assistance package, in which every household in the state received a $\$ 200$ rebate on their electricity bill to assist with household electricity and water costs [10]. This policy was announced by the Deputy Premier as in response to the additional cost in electricity and water of remaining at home [11]. This incentive was available to Queensland households only, with many other states providing targeted support for those affected by COVID-19, but not specifically targeting energy bills. There is not yet data available on the effect of the scheme on power use.

Table 1. Indicative timeline of COVID-19 lockdown in Queensland.

\begin{tabular}{ll}
\hline \multicolumn{1}{c}{ Date } & \multicolumn{1}{c}{ Description } \\
\hline 16 March & Some Queensland universities suspend all classroom teaching, instigating a move online ${ }^{1}$ \\
\hline 20 March & Australian borders closed to all non-residents ${ }^{2}$ \\
\hline 22 March & $\begin{array}{l}\text { Level } 2 \text { lockdown: Social distancing rules imposed, non-essential services cut, pubs, clubs, } \\
\text { bars, gyms, entertainment venues shut, restaurants, cafes etc., restricted to take-away } \\
\text { service only }\end{array}$ \\
\hline 30 March & Schools begin going student-free, aside from children of essential workers ${ }^{4}$ \\
\hline 2 April & $\begin{array}{l}\text { Level } 3 \text { lockdown: "A person must not leave their principal place of residence except for } \\
\text { essential needs including work, food, medical and exercise, outdoor gatherings only up to }\end{array}$ \\
\hline 2 persons or with members of household" ${ }^{3}$
\end{tabular}


Table 1. Cont.

\begin{tabular}{|c|c|}
\hline Date & Description \\
\hline 1 June & $\begin{array}{l}\text { Restaurants, pubs and other venues allowed to re-open with restrictions on capacity and } \\
\text { distancing } 11\end{array}$ \\
\hline 10 July & Easing of restrictions on gatherings, sporting events 12 \\
\hline $\begin{array}{l}\text { Table no } \\
1 \mathrm{https}: / / \\
2 \mathrm{https}: / / \\
3 \mathrm{https}: / / \\
4 \mathrm{https}: / / \\
5 \mathrm{https}: / \\
\text { public-he } \\
6 \mathrm{https}: / / \\
7 \mathrm{https}: / / \\
8 \mathrm{https}: / / \\
9 \mathrm{https://} \\
10 \mathrm{https} / / \\
11 \mathrm{https}: / / \\
12 \mathrm{https} /\end{array}$ & 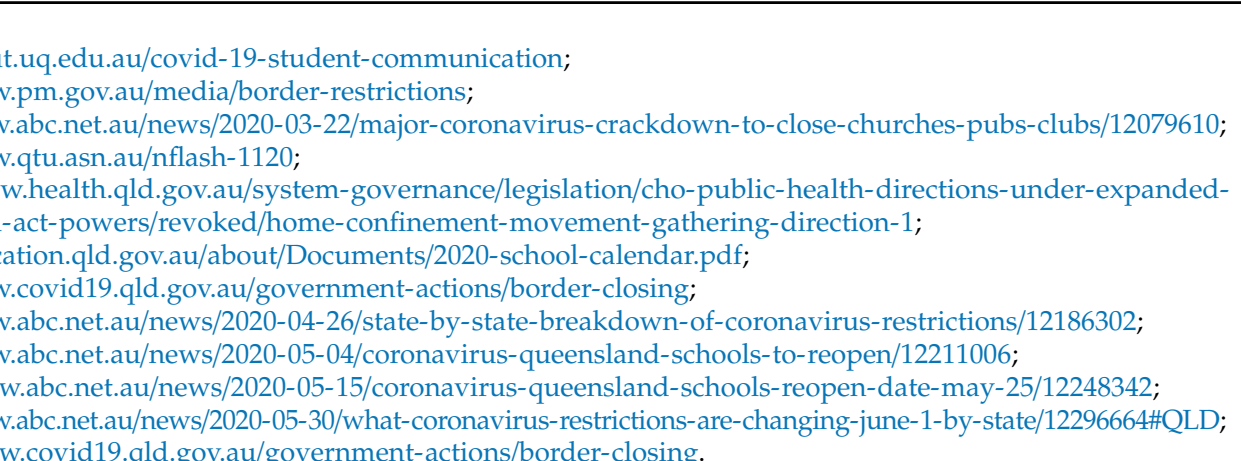 \\
\hline
\end{tabular}

\subsection{Understanding Load Profiles during Lockdown}

COVID-19 affected energy grids differently to sudden "shocks," earthquakes, or cyclones, where parts of the grid required repair or re-starting [12]. Extended power loss in these scenarios typically relates to the need for an incremental "restart" of the grid to avoid over-voltage [13]. Instead, COVID-19 produced relatively minor fluctuations in demand [4]. Modelling of total energy demand in Australia (including industrial and commercial loads) during COVID-19 shows a decrease in overall energy demand throughout April, yet substantial increases in residential energy demand, up to $14 \%$ in Victoria [4]. The lack of smart metering in states other than Victoria [5] reduces the ability for networks to isolate residential or commercial loads from total load data. Analysis of daily profiles finds the morning energy usage peak occurred later during lockdown, indicative of workers shifting their routines later to compensate for reductions in the morning commute [8]. Given significant residential demand increases reported elsewhere [3,4], we hypothesise that those households who have increased occupancy due to working, schooling at home or unemployment will have increased energy consumption.

In this present study, high frequency ( $1 \mathrm{~min}$ ) energy monitoring from 491 households across all states in Australia and additional 1 min per-circuit monitoring of 17 households in the state of Queensland, allows the quantification of changes to specific practices, e.g., heating/cooling, cooking, and lighting. This data is triangulated with in-depth qualitative interviews in order to provide personal accounts of the effect of increasingly restrictive lockdown measures on routines, behaviour, and energy use.

\subsection{Energy Monitoring}

A second priority of this study is to understand users' information needs with regard to electricity use in exceptional circumstances. For the householder, electricity is "doubly invisible", in that it cannot be seen physically and users typically lack point-of-sale information [14]. Energy use feedback can engage households with their energy use [15-19], yet the majority of Australians still only receive quantification of their energy use once per quarter [20]. Energy use feedback can produce average energy savings of over 10\% [15] and can increase householders' competency with energy use [21,22]. Yet initial energy savings are not always resilient over the long term and monitors can become disused [23]. The nature of users' interactions with energy feedback also changes over time; Li et al. [24] characterises two primary phases of reflection on personal data: "Discovery" (exploring one's data, observing trends and gathering additional information) and "Maintenance" (less frequent interactions, checking nothing is out of the ordinary) [24]. Users transition to the Maintenance phase when they 
learn typical patterns and the factors affecting their data and may transition back and forth between Discovery and Maintenance on occasions when the monitored information becomes salient again [24], e.g., a bill arrives or a change in household size occurs [21]. Our research provides novel insights into householder engagement with energy use feedback during COVID-19 restrictions, and how this feedback addresses householders' information needs at a time when many households' consumption patterns have changed.

\subsection{Hypotheses}

Based on the literature above, this study tests two hypotheses:

(1) Energy use among Queensland households will increase during lockdown compared to pre-lockdown, as per residential demand trends elsewhere [4].

(2) Self-reported engagement with energy will increase during lockdown, as changes to routines and circumstances transition users into another Discovery phase (based on Li et al. [24]).

\section{Methods}

\subsection{Smart Inverter Data}

Data were gathered from 491 homes in six Australian states in which a smart solar inverter was present. The inverter keeps track of the total load in each house in $\mathrm{kWh}$, at a resolution of $0.1 \mathrm{kWh}$, with a counter which is reset each day at midnight UTC (Universal Time), sampling electricity load at one-minute granularity. Consumption refers to gross consumption in all instances and not net consumption if/where solar panels are present. Demographic data is not available for these households, but all owned rooftop solar panels. The dataset includes data from February to May 2020. For each house, we performed paired $t$-tests at the 0.05 significance level comparing mean weekday pre-lockdown daily $\mathrm{kWh}$ electricity consumption of houses in each state to that of during lockdown. The "lockdown" period is defined as 21 March (the day before Level 2 lockdown was initiated) and 8 May (the Friday before school resumed refer Table 1). The pre-lockdown period is defined as 1 February to 19 March, immediately prior to lockdown, during which no restrictions were in place. The paired $t$-tests were repeated for weekday usage between the hours of 9 a.m. and 5 p.m. (the usual weekday business hours for Australian residents) and between 21 March to 8 May 2019 to enable a year-on-year comparison. Seasonality is partially controlled for in the 491 household dataset (where per circuit data is not available) by comparing 2020 (lockdown) results with those of the same periods of time in 2019 to better isolate the effect of lockdown relative to seasonal factors.

\subsection{Per-Circuit Energy Data}

Additionally, energy use and self-reported data were gathered from 19 households, 17 of which had satisfactory data (refer to Data Quality section below) throughout the dates listed above. WiFi-enabled "Phisaver" energy monitors utilising CT clamps [25] were fitted to 19 volunteer households in Brisbane, in the southeast of Queensland, Australia in November 2019, following elicitation of informed consent (UQ Ethics Approval \#NH03343). Participants were recruited through local community pages on social media advertising participation in an energy monitoring trial. No further incentives were provided, beyond access to the energy monitoring data.

The energy monitoring was set up in November 2019, three months prior to the introduction of social distancing restrictions in the state of Queensland [26]. Three months is sufficient time for the nature of interactions with energy use feedback to change [21] and for durable habits to be formed [27]. This timing serves to (1) eliminate the Hawthorne Effect with regard to changes of usage behaviours due to the energy monitoring, (2) ensure that users are beyond the initial Discovery (novelty) phase; enabling determination of whether and how COVID-19 restrictions affected reflection upon users' energy data, and (3) provide a robust prior dataset for quantitative comparison. Additional household-level electricity data was gathered from 491 homes with existing behind-the-meter monitoring from smart 
solar inverters, allowing a broader comparison of changes in energy use during COVID-19 with households from other states. This combination of data allows us to more accurately isolate the effect of COVID-19 lockdown on energy use from other factors such as changes in season.

Household characteristics and demographics are provided in Table 2. Prerequisites for participation ensured that all households: (1) lived in the greater Brisbane area, (2) owned their home (the install required a small box attached to the house), and (3) did not already have real-time feedback on their electricity consumption. The sample includes a mix of families and couples, as well as different dwelling types (e.g., brick, weatherboard, one/two stories) and is representative of the Queensland average of 33\% solar ownership and over 75\% air conditioning penetration [28]; however, we do not claim the sample is generalisable to the whole of Queensland.

Table 2. Household characteristics.

\begin{tabular}{|c|c|c|c|c|c|c|c|c|}
\hline ID & House Type & $\begin{array}{l}\text { Family } \\
\text { Composition }\end{array}$ & Ages & AC & PV & Pool & HW & $\begin{array}{c}\text { Typical } \\
\text { Bill }\end{array}$ \\
\hline P1 & $\begin{array}{c}\text { Detached } \\
\text { weatherboard, } \\
1 \text { story }\end{array}$ & $\begin{array}{c}2 \text { adults, } \\
2 \text { children }\end{array}$ & $40,36,6,1$ & $\checkmark$ & $\checkmark$ & & $\mathrm{HP}$ & $\begin{array}{l}\$ 120 \\
\text { credit }\end{array}$ \\
\hline $\mathrm{P} 2$ & $\begin{array}{c}\text { Detached } \\
\text { brick, } 2 \text { story }\end{array}$ & $\begin{array}{c}2 \text { adults, } \\
2 \text { children }\end{array}$ & $38,36,6,6$ & $\checkmark$ & $\checkmark$ & & $\mathrm{E}$ & $\$ 250$ \\
\hline P3 & $\begin{array}{c}\text { Detached, } \\
\text { weatherboard, } \\
1 \text { story }\end{array}$ & 2 adults & 49,46 & & & & GS & $\$ 600-\$ 700$ \\
\hline $\mathrm{P} 4$ & $\begin{array}{l}\text { Detached } \\
\text { brick, } 1 \text { story }\end{array}$ & $\begin{array}{l}1 \text { adult, } \\
4 \text { children }\end{array}$ & $\begin{array}{c}53,7,9,11 \\
16\end{array}$ & $\checkmark$ & & $\checkmark$ & S & $\$ 650-\$ 700$ \\
\hline P5 & $\begin{array}{c}\text { Detached } \\
\text { weatherboard, } \\
1 \text { story }\end{array}$ & $\begin{array}{c}2 \text { adults, } \\
2 \text { children }\end{array}$ & $41,37,3,1$ & $\checkmark$ & $\checkmark$ & & $\mathrm{E}$ & $\$ 200$ \\
\hline P6 & $\begin{array}{c}\text { Detached } \\
\text { brick, } 1 \text { story }\end{array}$ & $\begin{array}{c}2 \text { adults, } \\
4 \text { children }\end{array}$ & $\begin{array}{c}44,43 \\
5,7,12,14\end{array}$ & $\checkmark$ & & & $\mathrm{E}$ & $\$ 600$ \\
\hline P7 & $\begin{array}{c}\text { Detached } \\
\text { brick, } 1 \text { story }\end{array}$ & 2 adults & $70 \mathrm{~s}$ & $\checkmark$ & & $\checkmark$ & S & $\$ 395$ \\
\hline P8 & $\begin{array}{c}\text { Detached } \\
\text { weatherboard, } \\
1 \text { story }\end{array}$ & $\begin{array}{l}2 \text { adults, } \\
3 \text { children }\end{array}$ & $\begin{array}{c}40,37,13,12 \\
9\end{array}$ & $\checkmark$ & & & GI & $\$ 400$ \\
\hline P9 & $\begin{array}{c}\text { Detached } \\
\text { weatherboard, } \\
1 \text { story }\end{array}$ & 3 adults & $55,54,21$ & $\checkmark$ & & $\checkmark$ & GI & No data \\
\hline P10 & $\begin{array}{l}\text { Town house, } \\
\text { brick } 2 \text { story }\end{array}$ & 2 adults & 25,27 & $\checkmark$ & & & GI & $\$ 200$ \\
\hline P11 & $\begin{array}{c}\text { Detached } \\
\text { brick, } 1 \text { story }\end{array}$ & $\begin{array}{c}2 \text { adults, } \\
2 \text { teenagers }\end{array}$ & $52,50,17,14$ & $\checkmark$ & $\checkmark$ & & S & $\$ 200$ \\
\hline P12 & $\begin{array}{c}\text { Detached } \\
\text { weatherboard, } \\
1 \text { story }\end{array}$ & 2 adults & $60 \mathrm{~s}$ & $\checkmark$ & & & GI & $\$ 390$ \\
\hline P13 & $\begin{array}{c}\text { Detached } \\
\text { weatherboard, } \\
2 \text { story }\end{array}$ & $\begin{array}{c}2 \text { adults, } \\
2 \text { teenagers }\end{array}$ & $56,49,17,15$ & $\checkmark$ & $\checkmark$ & $\checkmark$ & GI & $\$ 500$ \\
\hline P14 & $\begin{array}{c}\text { Detached } \\
\text { brick, } 2 \text { story }\end{array}$ & $\begin{array}{c}2 \text { adults, } \\
3 \text { children }\end{array}$ & $47,39,4,4,4$ & $\checkmark$ & $\checkmark$ & $\checkmark$ & GS & $\$ 270$ \\
\hline P15 & $\begin{array}{c}\text { Detached } \\
\text { brick, } 2 \text { story }\end{array}$ & $\begin{array}{l}2 \text { adults, } \\
2 \text { children }\end{array}$ & $50,46,14,10$ & $\checkmark$ & $\checkmark$ & & $\mathrm{E}$ & $\$ 300$ \\
\hline
\end{tabular}


Table 2. Cont.

\begin{tabular}{|c|c|c|c|c|c|c|c|c|}
\hline ID & House Type & $\begin{array}{l}\text { Family } \\
\text { Composition }\end{array}$ & Ages & $\mathrm{AC}$ & PV & Pool & HW & $\begin{array}{c}\text { Typical } \\
\text { Bill }\end{array}$ \\
\hline P16 & $\begin{array}{l}\text { Apartment, } \\
\text { brick, } 1 \text { story }\end{array}$ & 2 adults & 30,30 & $\checkmark$ & & & $\mathrm{E}$ & $\$ 400$ \\
\hline P17 & $\begin{array}{c}\text { Detached } \\
\text { weatherboard, } \\
1 \text { story }\end{array}$ & $\begin{array}{l}2 \text { adults, } \\
4 \text { children }\end{array}$ & $\begin{array}{c}38,38,13,11 \\
8,6\end{array}$ & $\checkmark$ & & $\checkmark$ & S & $\$ 800$ \\
\hline P18 & $\begin{array}{l}\text { Detached } \\
\text { brick, } 1 \text { story }\end{array}$ & $\begin{array}{l}3 \text { adults, } \\
1 \text { child }\end{array}$ & $55,46,19,15$ & $\checkmark$ & & & $\mathrm{E}$ & $\$ 600$ \\
\hline P19 & $\begin{array}{l}\text { Town house, } \\
\text { brick, } 3 \text { story }\end{array}$ & $\begin{array}{c}2 \text { adults, } \\
1 \text { baby }\end{array}$ & $33,30,1$ & $\checkmark$ & & & $\mathrm{E}$ & $\$ 350$ \\
\hline
\end{tabular}

Table notes: $\mathrm{AC}=$ Air conditioning installed; $\mathrm{PV}=$ Rooftop solar PV installed; $\mathrm{HW}=$ Hot water service type $(\mathrm{E}=$ electric storage, $\mathrm{HP}=$ electric heat pump, $\mathrm{S}=$ solar, $\mathrm{GI}=$ Gas instantaneous, $\mathrm{GS}=$ Gas storage); Typical bill = self-reported typical quarterly bill amount, prior to installation of Phisaver.

Post installation, each household was given a short demonstration of the "Phisaver" energy monitoring dashboard and supplied with their username and password for the web-login which could be accessed on a PC, tablet, or phone. The energy monitors measure power continuously from each circuit in each house's meter box, aggregating to 10-s datapoints which are sent to a cloud-based server and visualised on each of the participants' Phisaver dashboards (Figure 1).

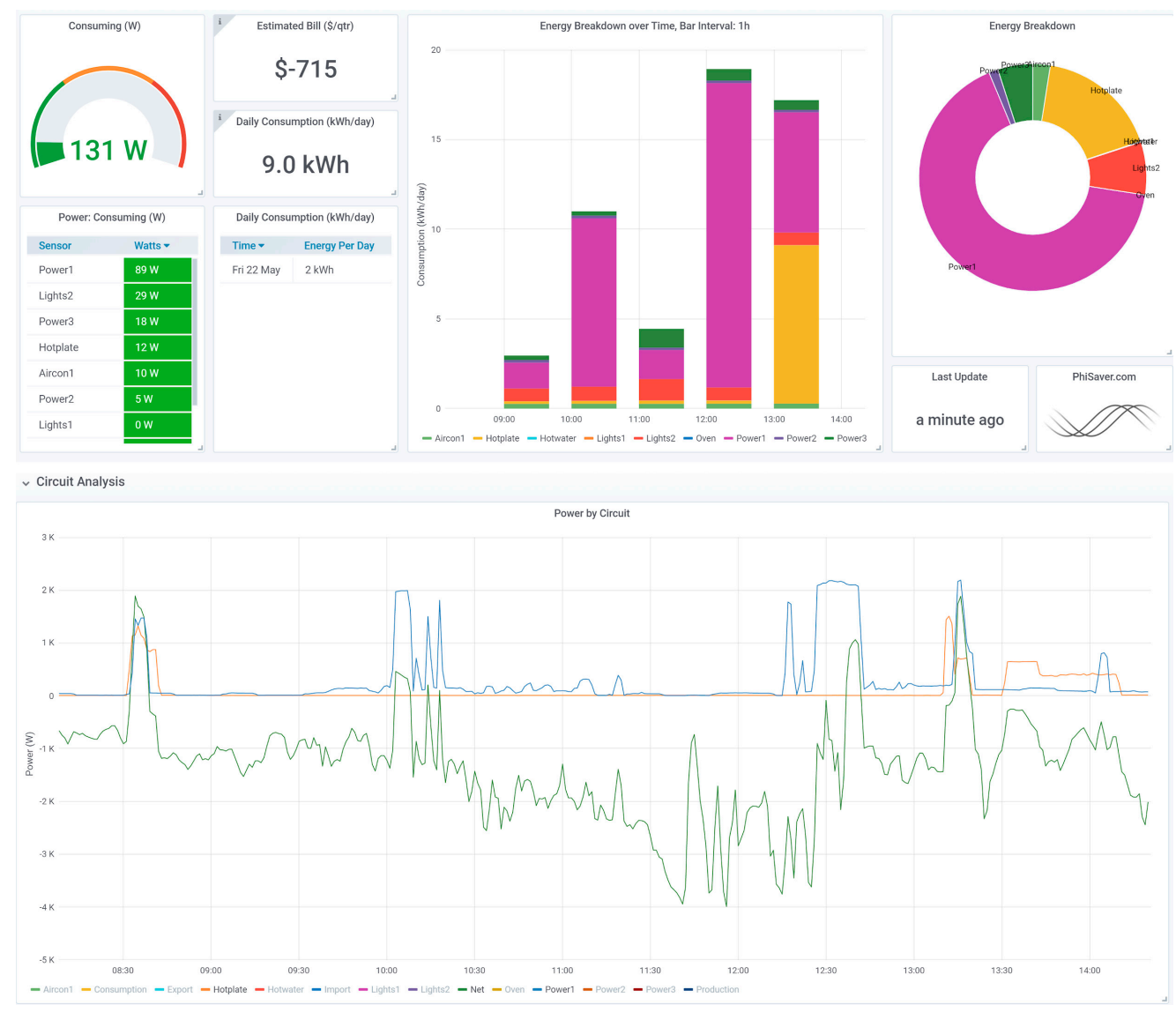

Figure 1. Phisaver energy monitoring interface available to all participants, PC view.

Energy consumption totals (one-minute frequency) were downloaded from the Phisaver cloud server from the period 1 February to 8 May 2020 and the one-minute resolution data from the houses 
was aggregated to hourly resolution. Some mislabelled circuits were identified to be heating or cooling circuits and removed, and circuits related to net usage, consumption, solar production, import, export, voltage, and unknown values were also removed. After data cleaning, circuits in each dataset were combined to form "Cooking" (stove, oven, or hotplate usage), "Lighting" (sum of all lighting circuits), and "PP" (sum of all power point circuits) groups for each house. These groupings should be considered indicative only, as some cooking activity such as microwaves, rice cookers, electric frypans etc., will be absorbed within the power points data.

To isolate the effect of energy use changes attributable to COVID-19, relative to effects which may have occurred regardless due to changes in season, all Air Conditioning and Hot Water circuits were removed from the analysis. This allows us to examine specifically the changes to power points, hotplate/oven, and lighting circuits, providing an excellent isolation of the energy use changes attributable to lockdown relative to weather. For the purposes of analysis, we do not treat lighting as seasonal in Queensland, given Brisbane's latitude means the change in sunset time is less than one hour between 21 March and 8 May. (Source: https:/www.timeanddate.com/sun/australia/Brisbane). The dominance of low energy LED and CFL lighting in Australia means that lighting is not a significant contributor to overall energy use [29].

\subsection{Self-Reported Data and Analysis}

Interviews for this study were conducted over Zoom or telephone between April and May 2020. Questions related to the effect of COVID-19 restrictions on each household's routine and occupancy patterns, self-reported changes to energy consumption, and self-reported engagement with the Phisaver dashboard during lockdown. Prior to this round of interviews, participants had taken part in two earlier interviews: (1) at installation, where demographics, building factors, and key appliances (e.g., air conditioning, hot water type, solar PV) were noted and (2) in-person interviews 4-6 weeks after installation to understand initial engagement with the Phisaver dashboard. As well as categorising responses according to questions, a thematic analysis based on Bruan and Clarke [30] was used to discover common themes across participants.

\subsection{Data Quality and Analysis}

Per-circuit monitoring: Energy use data is available from 17 of the 19 houses with per-circuit monitoring. Two devices (P1 and P4) were offline during periods of time, limiting the ability to reliably draw before/after lockdown comparisons. Two participants could not be contacted for the lockdown interview (P4 and P9) and a third suffered a major health incident precluding their participation (P7). $\mathrm{P} 4$ is excluded from the analysis having neither self-reported or sufficient qualitative data. Seasonality is controlled for in this dataset by excluding air conditioning circuits and hot water circuits from analysis. Independent $t$-tests were used to determine the magnitude and significance of changes to energy use in each circuit or circuit grouping (e.g., powerpoints, cooking, hot water etc) across this sample. Kernel density estimate plots were used to provide a visual comparison of these changes.

Smart inverter data: The initial smart inverter data contains data from 3006 houses. All houses with average energy consumption values of less than $0.1 \mathrm{kWh}$ or greater than $100 \mathrm{kWh}$ per day (either before or after lockdown) were excluded to ensure data quality. The standard deviation of the energy before/after lockdown was calculated, and houses where this was zero were excluded. Similarly, if the mean before/after lockdown was the same, or there were three or more days with the same recorded energy (at $0.1 \mathrm{kWh}$ resolution), or there were 11 or more days with the energy change in the same direction (that is, positive or negative), these houses were excluded. The last three days of March 2020 were also excluded because data was unavailable. Following this filtering process, 491 houses remained. The use of paired $t$-tests reflects the paired nature of the data (i.e., before/during lockdown data from the same household). Mean weekday daily kWh consumption values were calculated pre and during lockdown for each Australian state and paired $t$-tests ran on each state. 
As mentioned, seasonality is partially controlled for in this dataset by comparing 2020 (lockdown) results with those of the same periods of time in 2019.

\section{Results}

In this section, we describe the measured changes to electricity use across the 491 Australian households, before focusing on the specific drivers of these changes, reporting on the sample of 17 households with detailed per-circuit electricity monitoring, and participants' own insights gathered through the qualitative interview process. We focus in particular on results from Queensland, where the per-circuit monitoring and self-reported data is drawn from.

\subsection{Smart Inverter Data}

Average energy use patterns throughout the sample were plotted for weekdays (Figure 2). Here, "load" refers to the total energy usage within the houses in each state. Pre-lockdown refers to 1 February to 19 March 2020 and lockdown refers to 21 March to 8 May 2020. The steeper increase in energy use in the morning in NSW_ACT, VIC and TAS during lockdown (red line) may potentially be due to increased morning heating throughout April and May as the weather cooled. The decrease in energy use during lockdown is notable in QLD, where pre- and during-lockdown energy use follow a similar pattern throughout the day, but with notably lower average energy use during lockdown. In each instance it can be seen that lockdown does not greatly alter the usage profile throughout the day, however, the evening peaks in NSW_ACT, VIC, SA, and TAS during lockdown are notable, perhaps indicative of a greater number of residents remaining at home and eating at home on a larger number of nights during lockdown.
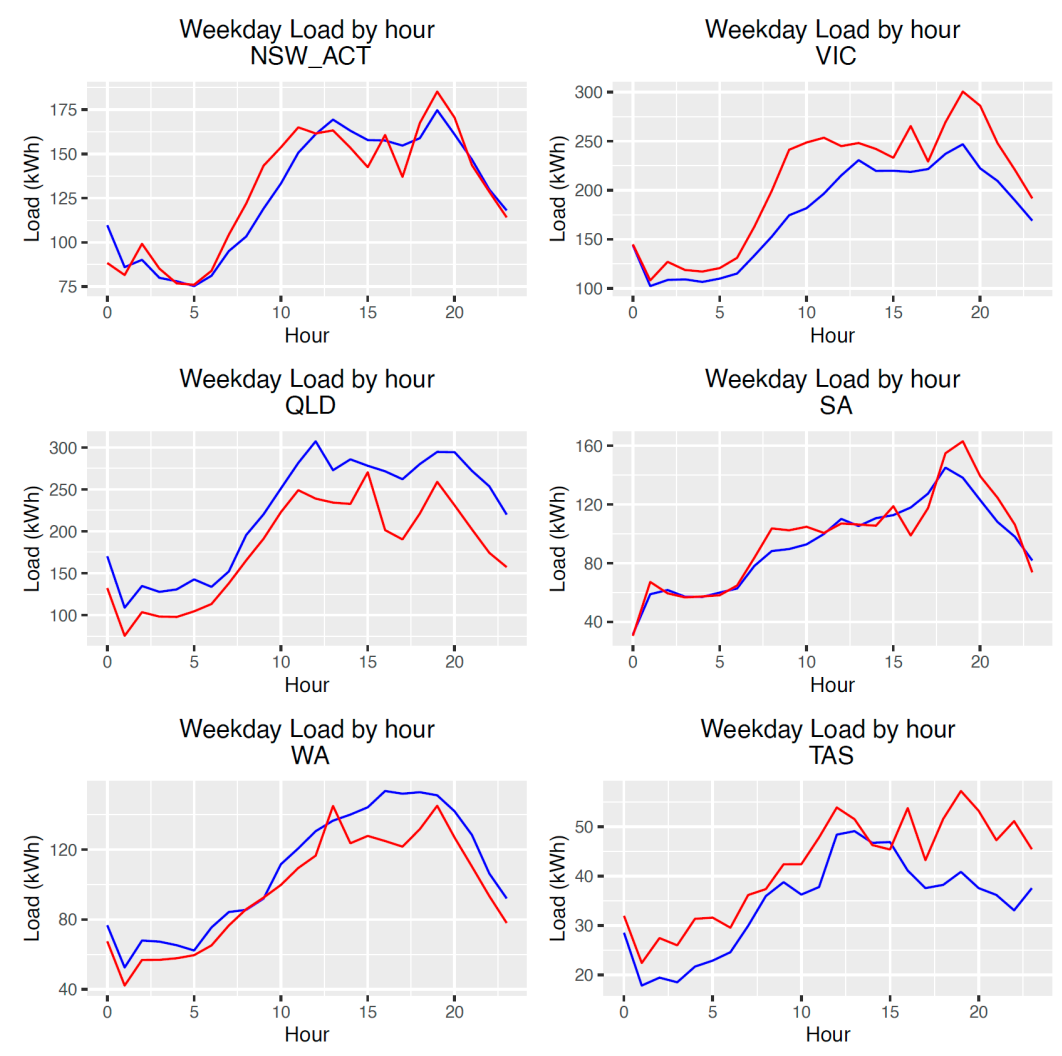

Figure 2. Hourly consumption weekday totals presented as line graphs for all households by state. Blue: pre-lockdown, Red: lockdown. $\mathrm{X}$ axis: time of day, $\mathrm{Y}$ axis: cumulative load of all monitored households for each preceding hour (e.g., $10 \mathrm{am}=$ energy used between 9-10 am). 
Paired $t$-tests on the mean daily energy usage for each state were conducted. Table 3a (weekdays overall) and Table $3 \mathrm{~b}$ (weekday 9 am to $5 \mathrm{pm}$ only) show results from the smart inverter data from 491 Australian households across each state, listing significant decreases vs. significant increases in power use on weekdays during COVID-19 lockdown relative to pre-lockdown.

Table 3. (a,b): Significant changes in weekday energy use during COVID-19 lockdown (21 March to 8 May) relative to the period prior to lockdown (1 February to 19 March) from smart inverter data, overall use during weekdays (a) and weekdays 9 am to 5 pm only (b).

\begin{tabular}{|c|c|c|c|c|c|}
\hline \multicolumn{6}{|c|}{ a: Overall Weekdays } \\
\hline Location & $\begin{array}{l}\text { Home } \\
\text { Count }\end{array}$ & $\begin{array}{c}\text { Mean Daily } \\
\text { Consumption } \\
\text { Pre-Lockdown (kWh) }\end{array}$ & $\begin{array}{l}\text { Change in Energy } \\
\text { Use }(\mathrm{kWh})(95 \% \mathrm{CI})\end{array}$ & $\begin{array}{l}\text { Percent } \\
\text { Change }\end{array}$ & $p$-Value \\
\hline Queensland (QLD) & 119 & 20.14 & $-2.54(-3.73--1.34)$ & $\downarrow 12.6 \%$ & $<0.01$ \\
\hline New South Wales (NSW) * & 78 & 17.13 & $0.74(-0.43-1.91)$ & $\uparrow 4.3 \%$ & 0.21 \\
\hline Victoria (VIC) & 134 & 14.67 & $2.80(1.97-3.64)$ & $\uparrow 19.1 \%$ & $<0.01$ \\
\hline South Australia (SA) & 75 & 13.18 & $0.87(-0.12-1.87)$ & $\uparrow 6.6 \%$ & 0.084 \\
\hline Western Australia (WA) & 53 & 22.22 & $-1.66(-3.51-0.19)$ & $\uparrow 7.5 \%$ & 0.077 \\
\hline Tasmania (TAS) & 32 & 17.48 & $3.46(0.98-5.94)$ & $\uparrow 19.9 \%$ & $<0.01$ \\
\hline Total & 491 & & & & \\
\hline \multicolumn{6}{|c|}{ b: 9 am to 5 pm Weekdays } \\
\hline Location & $\begin{array}{l}\text { Home } \\
\text { Count }\end{array}$ & $\begin{array}{c}\text { Mean Daily } \\
\text { Consumption } \\
\text { Pre-Lockdown (kWh) }\end{array}$ & $\begin{array}{l}\text { Change in Energy } \\
\text { Use (kWh) }(95 \% \mathrm{CI})\end{array}$ & $\begin{array}{l}\text { Percent } \\
\text { Change }\end{array}$ & $p$-Value \\
\hline Queensland (QLD) & 119 & 7.27 & $-1.01(-1.52--0.50)$ & $\downarrow 13.1 \%$ & $<0.01$ \\
\hline New South Wales (NSW) * & 78 & 6.05 & $-0.04(-0.59-0.51)$ & $\downarrow 0.7 \%$ & 0.88 \\
\hline Victoria (VIC) & 134 & 5.00 & $0.74(0.43-1.05)$ & $\uparrow 14.8 \%$ & $<0.01$ \\
\hline South Australia (SA) & 75 & 4.21 & $0.00(-0.35-0.36)$ & $0 \%$ & 0.98 \\
\hline Western Australia (WA) & 53 & 6.72 & $-0.17(-0.83-0.48)$ & $\downarrow 2.5 \%$ & 0.59 \\
\hline Tasmania (TAS) & 32 & 6.60 & $0.24(-1.06-1.53)$ & $\uparrow 3.6 \%$ & 0.71 \\
\hline Total & 491 & & & & \\
\hline
\end{tabular}

In the overall weekday analysis (Table 3a) we find that in Queensland, there is a significant $(p<0.01)$ decrease in energy use during lockdown relative to prior to lockdown, while in the southern states of Victoria and Tasmania there is a significant $(p<0.01)$ increase in energy use over the same period. In the 9 am to $5 \mathrm{pm}$ weekday analysis (Table 3b) the same pattern is observed, with a significant decrease in energy use in Queensland and a significant increase in energy use in Victoria during lockdown relative to prior to lockdown. Tasmania does not record significant change between 9 am to $5 \mathrm{pm}$, which may possibly be due to heating in the evening and early morning and switching heating off during the day.

\subsection{Comparison to 2019}

In order to better isolate the changes in energy use due to COVID-19 lockdown relative to seasonal factors (noting 1 February to 19 March is typically warmer than 21 March to 8 May in many parts of Australia [31]), paired $t$-tests were run to compare the energy use changes between 1 Feb to 19 March 2019 versus 21 March to 8 May 2019 to observe changes in energy use between these periods without the influence of COVID-19 lockdown. Table 4a,b below shows the significant changes in energy use. The inverters studied here are from households in six states which had satisfactory data for 2019, totaling 99 households. 
Table 4. (a,b) Significant changes in energy use from 1 February to 19 March 2019 compared to 21 March to 8 May 2019 from smart inverter data: overall use during weekdays (a), and 9 am to 5 pm weekdays only (b).

\begin{tabular}{|c|c|c|c|c|c|}
\hline \multicolumn{6}{|c|}{ a: Overall Weekdays } \\
\hline Location & $\begin{array}{l}\text { Home } \\
\text { Count }\end{array}$ & $\begin{array}{l}\text { Mean Daily } \\
\text { Consumption 1 February } \\
\text { to } 19 \text { March } 2019(\mathrm{kWh})\end{array}$ & $\begin{array}{l}\text { Change in Energy } \\
\text { Use }(\mathrm{kWh})(95 \% \mathrm{CI})\end{array}$ & $\begin{array}{l}\text { Percent } \\
\text { Change }\end{array}$ & $p$-Value \\
\hline Queensland (QLD) & 26 & 23.26 & $-5.09(-7.03--3.16)$ & $\downarrow 21.9 \%$ & $<0.01$ \\
\hline New South Wales (NSW) * & 19 & 17.38 & $0.82(-5.90-7.54)$ & $\uparrow 4.7 \%$ & 0.80 \\
\hline Victoria (VIC) & 27 & 18.13 & $-0.09(-1.60-1.42)$ & $\downarrow 0.5 \%$ & 0.90 \\
\hline South Australia (SA) & 11 & 15.58 & $-0.95(-2.55-0.65)$ & $\downarrow 6.1 \%$ & 0.21 \\
\hline Western Australia (WA) & 12 & 20.87 & $0.15(-4.88-5.18)$ & $\uparrow 0.7 \%$ & 0.95 \\
\hline Tasmania (TAS) & 4 & 12.85 & $1.80(-3.28-6.87)$ & $\uparrow 14.0 \%$ & 0.34 \\
\hline Total & 99 & & & & \\
\hline \multicolumn{6}{|c|}{ b: 9 am to $5 \mathrm{pm}$ Weekdays } \\
\hline Location & $\begin{array}{l}\text { Home } \\
\text { Count }\end{array}$ & $\begin{array}{l}\text { Mean Daily } \\
\text { Consumption } 1 \text { February } \\
\text { to } 19 \text { March } 2019(\mathrm{kWh})\end{array}$ & $\begin{array}{l}\text { Change in Energy } \\
\text { Use (kWh) }(95 \% \text { CI) }\end{array}$ & $\begin{array}{l}\text { Percent } \\
\text { Change }\end{array}$ & $p$-Value \\
\hline Queensland (QLD) & 26 & 9.27 & $-2.19(-3.09--1.29)$ & $\downarrow 23.6 \%$ & $<0.01$ \\
\hline New South Wales (NSW) * & 19 & 6.58 & $0.10(-3.68-3.87)$ & $\uparrow 1.5 \%$ & 0.96 \\
\hline Victoria (VIC) & 27 & 7.38 & $-1.01(-1.75--0.27)$ & $\downarrow 13.7 \%$ & $<0.01$ \\
\hline South Australia (SA) & 11 & 5.52 & $-0.89(-1.88-0.11)$ & $\downarrow 16.1 \%$ & 0.075 \\
\hline Western Australia (WA) & 12 & 5.93 & $-0.03(-1.02-0.96)$ & $\downarrow 0.5 \%$ & 0.94 \\
\hline Tasmania (TAS) & 4 & 4.81 & $0.09(-0.65-0.83)$ & $\downarrow 1.9 \%$ & 0.72 \\
\hline Total & 99 & & & & \\
\hline
\end{tabular}

As in Table 3a,b, the Queensland houses in the sample recorded a significant decrease in energy usage in 2019, potentially due to a decrease in air conditioning; however, the decrease in energy usage is greater in 2019 (Table 3a) than in 2020 (Table 4a). No other states record significant changes in overall energy use during weekdays during this period, while Victorian houses record a significant energy usage decrease in peak hours ( 9 am-5 pm) in 2019 (Table $4 \mathrm{~b}$ ); compared to an increase in peak hours in 2020.

It is useful to understand whether 2019 and 2020 are comparable years climatically when using 2019 energy use data as a means of controlling for seasonality. Table 5 below shows the hourly average temperatures, measured using the Universal Thermal Comfort Index (UTCI) [32] values from the Copernicus Climate Data Store, in the six states, for the corresponding periods. The UTCI is based upon multiple factors including temperature, relative humidity and windspeed to accurately profile thermal stress due to weather conditions. The values range can be interpreted where 0-9: slight cold stress; 9-26: no thermal stress; 26-32: moderate heat stress [32].

Overall there is relatively little variance in average UTCI values between 2019 and 2020 (Table 5). The UTCI values also highlight the likelihood of heating versus cooling use. For example, Adelaide, Melbourne, and Hobart have UTCI values below 9 "slight cool stress" from March-May (all weekdays), indicating the likelihood heating being used, while Brisbane records values above the 26 "moderate heat stress" threshold during daytime ( 9 am-5 pm) between 1 February and 19 March, indicative that air conditioning use is likely during daylight hours. Table 5 also shows how locations which may require air conditioning prior to lockdown (e.g., Brisbane and Perth) will require less air conditioning after the lockdown date of 20 March, where all daytime UTCI values are within the 9-26 "no thermal stress" range. 
Table 5. Hourly temperature (UTCI) in six state capitals, pre and post COVID-19 lockdown, and corresponding 2019 periods.

\begin{tabular}{|c|c|c|c|c|c|}
\hline & & $\begin{array}{c}1 \text { February to } \\
19 \text { March } 2019\end{array}$ & $\begin{array}{l}21 \text { March to } \\
11 \text { May } 2019\end{array}$ & $\begin{array}{l}1 \text { February to } \\
19 \text { Mar } 2020\end{array}$ & $\begin{array}{l}21 \text { March to } \\
11 \text { May } 2020\end{array}$ \\
\hline \multirow{6}{*}{ All weekdays } & Brisbane (QLD) & 24.9 & 18.7 & 24.2 & 18.6 \\
\hline & Sydney (NSW) & 21.1 & 15.3 & 19.4 & 13.4 \\
\hline & Melbourne (VIC) & 17.6 & 9.8 & 15.6 & 8.1 \\
\hline & Adelaide (SA) & 15.7 & 9.6 & 14.1 & 8.3 \\
\hline & Perth (WA) & 21.3 & 13.1 & 22.1 & 14.7 \\
\hline & Hobart (TAS) & 11.5 & 6 & 10.3 & 6.4 \\
\hline \multirow{6}{*}{$\begin{array}{c}\text { Peak weekdays } \\
(9 \mathrm{am}-5 \mathrm{pm})\end{array}$} & Brisbane (QLD) & 30.3 & 24 & 28.7 & 24.6 \\
\hline & Sydney (NSW) & 25.7 & 21.4 & 23.6 & 19.1 \\
\hline & Melbourne (VIC) & 24.5 & 16.5 & 21.8 & 14.2 \\
\hline & Adelaide (SA) & 20.9 & 14.8 & 19.6 & 13 \\
\hline & Perth (WA) & 26.6 & 17.8 & 26.6 & 19.1 \\
\hline & Hobart (TAS) & 16.2 & 11 & 15.6 & 11 \\
\hline
\end{tabular}

Table 6 provides a summary of the percentage changes in energy use in the pre and during lockdown periods in 2020 with the corresponding periods in 2019.

Table 6. Comparison of percentage increases/decreases in energy use between 21 March to 11 May versus 1 February to 19 March in 2019 and 2020, for both overall energy use and energy use between 9 am-5 pm only.

\begin{tabular}{|c|c|c|c|c|}
\hline Location & $\begin{array}{l}\text { Pre vs. during } \\
\text { Lockdown Period } \\
2019 \text { (Overall) }\end{array}$ & $\begin{array}{l}\text { Pre vs. during } \\
\text { Lockdown Period } \\
2020 \text { (Overall) }\end{array}$ & $\begin{array}{c}\text { Pre vs. during } \\
\text { Lockdown Period } \\
2019(9 \text { am }-5 \text { pm) }\end{array}$ & $\begin{array}{l}\text { Pre vs. during } \\
\text { Lockdown Period } \\
2020(9 \text { am }-5 \text { pm) }\end{array}$ \\
\hline Queensland (QLD) & $\downarrow 21.9 \%$ & $\downarrow 12.6 \%$ & $\downarrow 23.6 \%$ & $\downarrow 13.1 \%$ \\
\hline New South Wales (NSW) * & $\uparrow 4.7 \%$ & $\uparrow 4.3 \%$ & $\uparrow 1.5 \%$ & $\downarrow 0.7 \%$ \\
\hline Victoria (VIC) & $\downarrow 0.5 \%$ & $\uparrow 19.1 \%$ & $\downarrow 13.7 \%$ & $\uparrow 14.8 \%$ \\
\hline South Australia (SA) & $\downarrow 6.1 \%$ & $\uparrow 6.6 \%$ & $\downarrow 16.1 \%$ & $0 \%$ \\
\hline Western Australia (WA) & $\uparrow 0.7 \%$ & $\uparrow 7.5 \%$ & $\downarrow 0.5 \%$ & $\downarrow 2.5 \%$ \\
\hline Tasmania (TAS) & $\uparrow 14.0 \%$ & $\uparrow 19.9 \%$ & $\downarrow 1.9 \%$ & $\uparrow 3.6 \%$ \\
\hline Total & & & & \\
\hline
\end{tabular}

Lockdown can be seen to have a substantial effect on household consumption (Table 6). In Queensland, household's energy use decreased on average by much less in March-May 2020 versus March-May 2019 relative to the February-March period in both years (Table 6), which may indicate an increase in other energy usage (e.g., cooking, cleaning, media) during lockdown contributing to the smaller reduction in 2020. A pronounced difference is also notable in Victoria and South Australia, where in Victoria, daytime energy use ( $9 \mathrm{am}-5 \mathrm{pm})$ decreased by $13.7 \%$ in March-May vs. February-March 2019, yet increased by almost 15\% in the corresponding periods in 2020, potentially indicative of a large effect of COVID-19 lockdown restrictions.

\subsection{Per-Circuit Monitoring}

Here we examine more closely the changes in electricity consumption of 17 Brisbane (Queensland) households with per-circuit monitoring. Our ability to control for seasonality by excluding air conditioning and hot water circuits from analysis allows us to interrogate more precisely how energy 
use in the home changed during lockdown. Table $7 \mathrm{a}, \mathrm{b}$ detail the average daily energy consumption changes in $\mathrm{kWh}$ for each energy use constituent and the $p$-values for the increases/decreases.

Table 7. (a,b) Significant changes in energy use by circuit, comparing COVID-19 lockdown (21 March to 8 May) relative to the period prior to lockdown (1 February to 19 March): overall weekdays (a) and 9 am to 5 pm weekdays (b).

\begin{tabular}{|c|c|c|c|c|c|}
\hline \multicolumn{6}{|c|}{ a: Overall Weekdays } \\
\hline & $\begin{array}{l}\text { Home } \\
\text { Count }\end{array}$ & $\begin{array}{l}\text { Mean Daily Energy Use } \\
\text { Pre-Lockdown (kWh) }\end{array}$ & $\begin{array}{l}\text { Changes in ENERGY } \\
\text { use }(\mathrm{kWh})(95 \% \mathrm{CI})\end{array}$ & $\begin{array}{l}\text { Percent } \\
\text { Change }\end{array}$ & $p$-Value \\
\hline Power points & 17 & 10.44 & $0.34(-0.43-1.11)$ & $\uparrow 3.3 \%$ & 0.37 \\
\hline Cooking & 17 & 0.80 & $0.28(0.17-0.39)$ & $\uparrow 35.0 \%$ & $<0.01$ \\
\hline Lighting & 17 & 2.11 & $-0.12(-0.59-0.35)$ & $\downarrow 5.7 \%$ & 0.59 \\
\hline All (excl. HW and AC) & 17 & 16.17 & $-0.06(-1.05-0.93)$ & $\downarrow 0.4 \%$ & 0.90 \\
\hline All (incl. HW and AC) & 17 & 23.00 & $-3.00(-5.60--0.40)$ & $\downarrow 13.0 \%$ & 0.027 \\
\hline \multicolumn{6}{|c|}{ b: 9 am to 5 pm Weekdays } \\
\hline & $\begin{array}{l}\text { Home } \\
\text { count }\end{array}$ & $\begin{array}{l}\text { Mean daily consumption } \\
\text { pre-lockdown (kWh) }\end{array}$ & $\begin{array}{l}\text { Changes in energy use } \\
(\mathrm{kWh})(95 \% \mathrm{CI})\end{array}$ & $\begin{array}{l}\text { Percent } \\
\text { change }\end{array}$ & $p$-value \\
\hline Power points & 17 & 3.87 & $0.46(0.03-0.89)$ & $\uparrow 11.9 \%$ & 0.037 \\
\hline Cooking & 17 & 0.56 & $0.21(0.12-0.30)$ & $\uparrow 37.5 \%$ & $<0.01$ \\
\hline Lighting & 17 & 0.56 & $0.10(-0.05-0.25)$ & $\uparrow 17.9 \%$ & 0.17 \\
\hline All (excl. HW and AC) & 17 & 6.40 & $0.43(-0.36-1.21)$ & $\uparrow 6.7 \%$ & 0.27 \\
\hline All (incl. HW and AC) & 17 & 8.86 & $-0.88(-2.12-0.36)$ & $\downarrow 9.9 \%$ & 0.15 \\
\hline
\end{tabular}

Energy usage for cooking increased significantly in the post-lockdown period, but energy use on other circuits (power points, lighting, and overall usage) did not change significantly. Between $9 \mathrm{am}$ and $5 \mathrm{pm}$, the incidence of significantly higher power consumption is more pronounced, with power points and cooking energy usage significantly increased and lighting energy use increasing by $17.9 \%$ (Table $7 \mathrm{~b}$ ). These increases in daytime energy use on the cooking, lighting, and power points circuits reflect the substantial self-reported changes to occupancy and routines necessitated by COVID-19 restrictions which are described by participants in the following section. The impact of air conditioning on overall energy use is clear, where despite the significant increases in cooking and power points circuits between 9 am to $5 \mathrm{pm}$ during lockdown, overall energy consumption (without controlling for seasonality) decreased significantly (Table $7 \mathrm{a}, \mathrm{b})$.

\subsection{Consumption Changes per Household}

In order to correlate participants' self-reported changes in routines with quantitative energy consumption data, it is necessary to analyse individual households' energy consumption. Figure 3 (below) shows how consumption changed over time on the power points circuits of each of the 17 households with per circuit monitoring using Kernel Density Estimation plots. Blue indicates pre-lockdown, red indicates post lockdown, with the area under each curve representing the average daily energy consumption.

The higher consumption from power points circuits during lockdown versus prior to lockdown for many participants is evident, given the lockdown (red) curves are typically located to the right of the pre-lockdown curves indicating a higher $\mathrm{kWh}$ consumption. The more uniform distribution of lockdown power point energy use observed in several participants' data (P7, P9, P10, P11, P12 $\mathrm{P} 16)$ is indicative of a greater consistency in energy use patterns per day. The visibly higher daytime power point consumption for P2, P5, P6, P10, P14, P15, P17, P18 correlates well to these participants' self-reported increase in digital device use described below. 
Independent $t$-tests were run to identify changes in each household's energy use, broken down by circuit grouping, as well as total consumption with/without including air conditioning and hot water circuits (Table 8). The number of independent tests run means there is some potential for type one errors; however, the table provides a useful indication of variance in usage per-participant.

In agreement with the results for Queensland households in the smart inverter dataset (Table $3 a$ and $3 b$ ), nine of the 17 houses used significantly less electricity during lockdown, with only three (P10, P16 and P17) using significantly more. After controlling for impacts of seasonality, results were more mixed, with three households having statistically significant increases in energy use during lockdown while two had significant decreases. All but one (P2) of the 17 houses used more electricity for cooking; six of these were statistically significant.
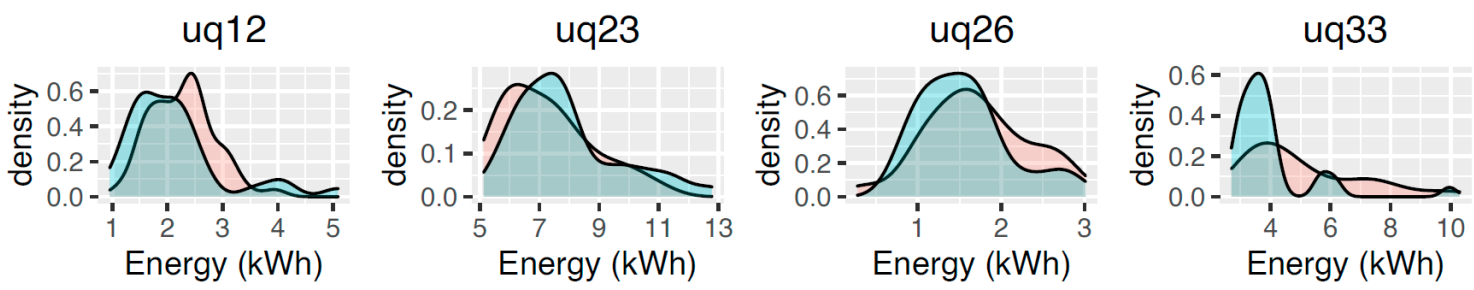

uq37
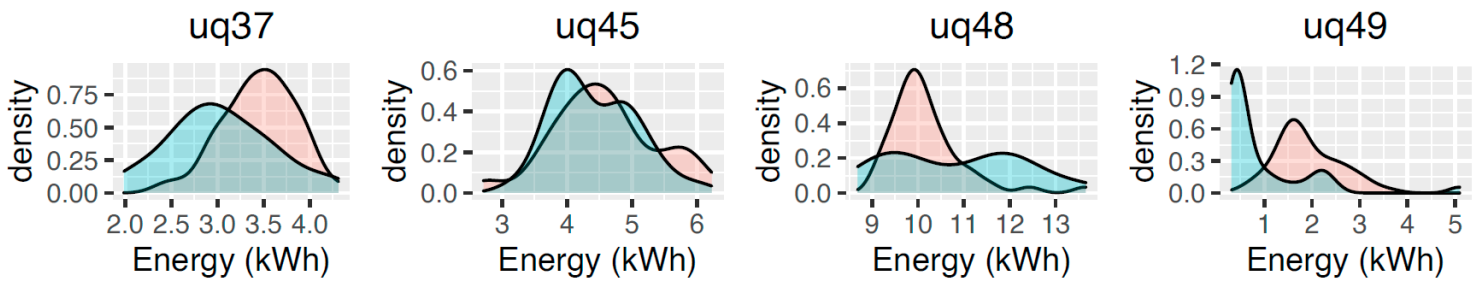

uq56
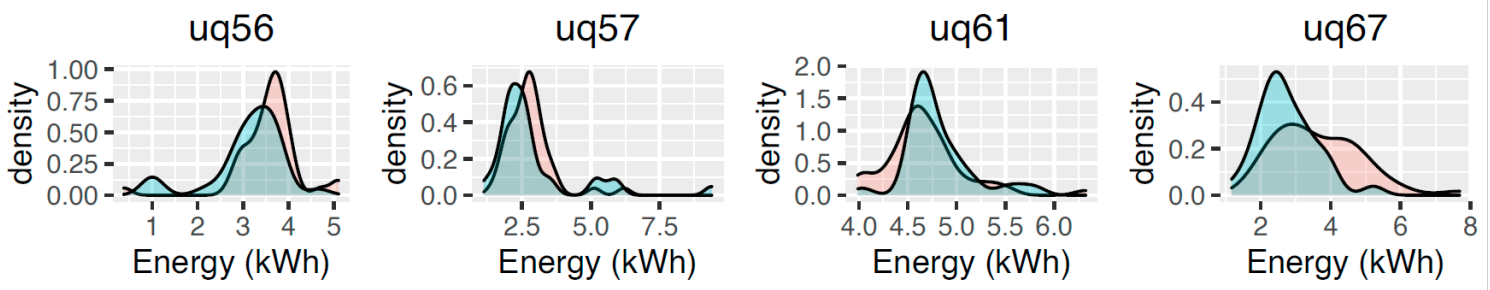

uq68
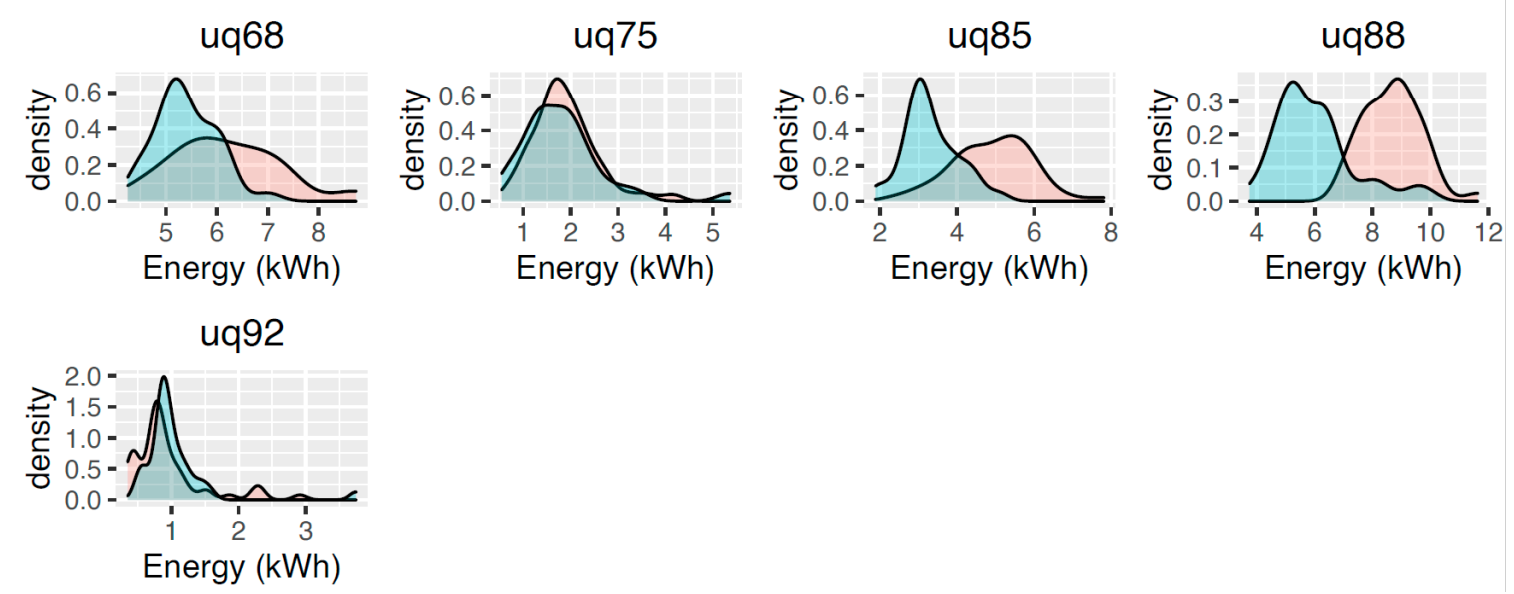

Figure 3. Power points circuits 9 am -5 pm weekday changes in energy use (after controlling for seasonality) pre-lockdown (blue) vs. during lockdown (red). 
Table 8. Overall changes in average daily weekday energy use during lockdown vs. pre-lockdown.

\begin{tabular}{|c|c|c|c|c|c|c|c|c|c|c|}
\hline ID & $\begin{array}{l}\text { PP \% } \\
\text { Change }\end{array}$ & $\begin{array}{c}\text { PP } \\
p \text {-Value }\end{array}$ & $\begin{array}{l}\text { Cook \% } \\
\text { Change }\end{array}$ & $\begin{array}{l}\text { Cook } \\
p \text {-Value }\end{array}$ & $\begin{array}{l}\text { Lights \% } \\
\text { Change }\end{array}$ & $\begin{array}{l}\text { Lights } \\
p \text {-Value }\end{array}$ & $\begin{array}{l}\text { All \% } \\
\text { Change }\end{array}$ & $\begin{array}{c}\text { All } \\
p \text {-Value }\end{array}$ & $\begin{array}{l}\text { Total Cons. } \\
\text { (AC + HW } \\
\text { incl) (\%) }\end{array}$ & $\begin{array}{c}\text { Total Cons. } \\
\text { (AC + HW } \\
\text { incl.) } p \text {-Value }\end{array}$ \\
\hline P12 & $4.6 \%$ & 0.290 & $-60.2 \%$ & 0.290 & $-18.1 \%$ & $<0.001$ & $0.4 \%$ & 0.923 & $-1.3 \%$ & 0.742 \\
\hline P23 * & $-13.4 \%$ & $<0.001$ & $3.7 \%$ & 0.950 & $-10.6 \%$ & 0.101 & $-12.9 \%$ & 0.001 & $-12.9 \%$ & 0.001 \\
\hline P26 & $4.1 \%$ & 0.362 & $33.0 \%$ & 0.018 & $-26.7 \%$ & $<0.001$ & $3.5 \%$ & 0.469 & $-10.1 \%$ & 0.086 \\
\hline P33 & $-4.3 \%$ & 0.280 & $83.9 \%$ & 0.119 & $45.2 \%$ & $<0.001$ & $3.6 \%$ & 0.381 & $-28.4 \%$ & $<0.001$ \\
\hline P37 & $9.5 \%$ & $<0.001$ & $16.3 \%$ & 0.380 & $-42.0 \%$ & 0.001 & $-0.9 \%$ & 0.589 & $-12.0 \%$ & 0.006 \\
\hline P45* & $-8.4 \%$ & $<0.001$ & $59.7 \%$ & 0.022 & $-3.6 \%$ & 0.682 & $-2.6 \%$ & 0.372 & $-16.3 \%$ & 0.001 \\
\hline P48* & $-3.5 \%$ & 0.190 & $124.3 \%$ & 0.027 & $14.0 \%$ & 0.172 & $-15.6 \%$ & 0.009 & $-15.0 \%$ & 0.012 \\
\hline P49 * & $84.0 \%$ & $<0.001$ & $91.5 \%$ & 0.028 & $-1.9 \%$ & 0.850 & $71.1 \%$ & $<0.001$ & $49.7 \%$ & $<0.001$ \\
\hline P56 & $9.3 \%$ & 0.077 & $32.0 \%$ & 0.168 & $-18.0 \%$ & 0.042 & $8.3 \%$ & 0.107 & $-40.4 \%$ & 0.002 \\
\hline P57 * & $1.0 \%$ & 0.872 & $129.7 \%$ & 0.006 & $5.6 \%$ & 0.619 & $4.7 \%$ & 0.487 & $-29.7 \%$ & 0.003 \\
\hline P61 * & $0.7 \%$ & 0.532 & $21.1 \%$ & 0.363 & $7.0 \%$ & 0.167 & $1.2 \%$ & 0.553 & $-5.6 \%$ & 0.375 \\
\hline P67 * & $3.3 \%$ & 0.469 & $55.2 \%$ & 0.210 & $7.8 \%$ & 0.248 & $-2.3 \%$ & 0.403 & $-11.7 \%$ & 0.005 \\
\hline P68 & $1.8 \%$ & 0.582 & $3.0 \%$ & 0.844 & $16.9 \%$ & $<0.001$ & $5.0 \%$ & 0.097 & $-20.7 \%$ & 0.005 \\
\hline P75 & $-1.3 \%$ & 0.809 & $77.8 \%$ & 0.036 & $5.0 \%$ & 0.649 & $5.2 \%$ & 0.390 & $11.9 \%$ & 0.007 \\
\hline P85 & $21.5 \%$ & $<0.001$ & $11.0 \%$ & 0.348 & $2.6 \%$ & 0.626 & $7.1 \%$ & 0.029 & $9.1 \%$ & 0.026 \\
\hline P88 & $23.7 \%$ & $<0.001$ & $44.8 \%$ & 0.070 & $-6.7 \%$ & 0.313 & $18.6 \%$ & $<0.001$ & $6.5 \%$ & 0.320 \\
\hline P92 & $4.3 \%$ & 0.504 & $14.4 \%$ & 0.600 & $-55.6 \%$ & $<0.001$ & $-5.6 \%$ & 0.345 & $-9.7 \%$ & 0.081 \\
\hline $\begin{array}{l}\text { Number } \\
\text { increased }\end{array}$ & 12 & 4 & 16 & 6 & 8 & 2 & 11 & 3 & 4 & 3 \\
\hline $\begin{array}{l}\text { Number } \\
\text { decreased }\end{array}$ & 5 & 2 & 0 & 0 & 9 & 5 & 6 & 2 & 13 & 9 \\
\hline
\end{tabular}

Bold = statistically significant $(p<0.05)$; Red $=$ decrease; ${ }^{*}$ Household owns gas cooktop and/or oven- \% changes to "cooking" may be based on small numbers.

\subsection{Self-Reported Changes in Energy Use}

Overall, many of the participants reported substantially disrupted routines as a result of lockdown. While none of the participants had themselves lost their jobs, two households (P3, P12) had an additional family member move in as a result of unemployment. P19's wife and baby daughter temporarily relocated to her parents' house as a precaution against his long hours in a customer-facing job, while P16 gave birth to a baby during lockdown in mid-April. Members from some households continued to leave the house to work throughout lockdown, including those families with essential workers such as teachers and health workers (P1, P5, P6) and others who were required to (P19) or chose to continue working at their normal place of work where restrictions allowed (P11, P13 and P18). P11 described this decision as: "If he was working from home he'd be sitting next to me all day!"

\subsection{Agreement with Quantitative Results}

Eleven of the 17 participants who took part in the interviews felt that their energy use had remained the same or increased since lockdown. This is in good agreement with the quantitative results after controlling for seasonality (Table 8), where 11 households had increased overall use, but in poor agreement with total energy consumption without controlling for seasonality where only four households increased electricity use during lockdown. The results suggest participants underestimate the effect of air conditioning on electricity use. Of those with significant increases (when controlling for seasonality) (Table 8) P10 had both household members working from home, both of whom normally left the house between 8 am- $5 \mathrm{pm}$. P16 reported substantially increased air conditioning and showering during the lockdown period, but attributed this to her newborn baby rather than lockdown. P17 had all four children and their father working and schooling from home throughout lockdown, when all would ordinarily be out of the home between 8 am and $4 \mathrm{pm}$. 
Of those who used less overall after controlling for seasonality (Table 8), P19's household size decreased when his wife and child relocated and P9 had a swimming pool where the filter pump is plugged into the power points circuit (rather than a dedicated circuit). The reduced hours of pool filtration necessary in autumn relative to summer may explain part of the decrease. P3's decrease may also be seasonal, as this household did not own an air conditioner and reported running fans almost continuously throughout summer, but less so during cooler months.

The increase in the majority of households' daytime power points and lighting circuits consumption during lockdown (Table 8) agrees with the widespread increases in self-reported digital device use (computers, laptops, tablets etc), including those brought home from school and/or work. Five households (P1, P2, P10, P11 and P14) reported an increase in digital device use for socialising and/or church beyond the existing increases due to working/studying from home.

\subsection{Energy Use Feedback}

Despite nearly all households identifying increases in certain aspects of their consumption, and all households having access to detailed eco-feedback dashboards, engagement with the eco-feedback was the lowest at any point in the six months since the units had been installed. All but three of the 17 participants reported accessing their dashboard less during lockdown than before lockdown and nine of the 17 participants interviewed had looked at their dashboard once or zero times throughout the entire lockdown period. For many participants this lack of engagement was attributed to other priorities, e.g., "all this stuff happening meant it wasn't on my mind" (P18) or being "distracted with other things" (P6). Others (P3, P10, P16 and P19) mentioned they had already learned their usual energy use patterns, and when they had last looked, nothing was out of order. Only P11, P13 and P17 had looked at it a similar amount or more; P17 had the dashboard on an always-on tablet in the kitchen and paid regular attention to it when he walked past when working from home, while P11 and P13 continued to access the dashboard as part of their internet browsing: "Yeah I continue to harass the kids with it [imitating herself] 'is that the hair straightener? Look how much energy you've wasted!" (P11).

\section{Discussion}

The unprecedented nature of the COVID-19 social distancing restrictions means that comparison to existing events is difficult. However, our results reflect previous findings that national events resulting in people remaining at home can significantly affect energy demand [33]. A significant effect on network demand was recorded across Australia as millions of households stayed home to watch certain events at the 2000 Sydney Olympics [33]. In relation to COVID-19 specifically, other studies show COVID-19-related demand changes across entire networks or nations $[3,4,8]$, yet our access to high granularity consumption information and per-circuit monitoring presents a novel and detailed snapshot of the effects of social distancing restrictions on the individual consumption patterns of Australian households. Our work builds on existing work identifying energy use patterns and behavioural drivers of consumption from smart metered data [34,35].

Comparing energy use changes during lockdown to the same periods in 2019 partially controls for seasonality and helps isolate the effect of COVID-19 restrictions from seasonal factors. Our findings indicate a seemingly substantial effect of lockdown on energy use in several states of Australia (Table 6). In Queensland, the reduction in energy use between March-May relative to February-March was less in 2020 than the same period in 2019, indicating an effect of lockdown. Yet, contrary to our expectations the additional energy used for cooking, reheating, entertainment, and working and learning from home during lockdown was still not sufficient to offset the reduction in air conditioning load during March-May relative to February-March. Remarkably, the majority of Queensland households' in the sample recorded decreases in overall energy use during COVID-19 lockdown relative to prior to lockdown, despite government-mandated regulations causing the majority of the population to stay at home [26]. Hypothesis 1 is not supported. These findings underscore the substantial contribution of 
cooling load to overall energy use in Queensland and the contribution of heating/cooling to Australian energy demand more generally [36].

In contrast, our hypothesis would have held for cooler southern Australian states such as Tasmania and Victoria where substantially more households increased their electricity use during lockdown relative to those who recorded decreases (Table $3 a, b$ and Table $4 a, b$ ). This may relate to increased daytime occupancy during lockdown and potentially an increased need for space heating as the weather cooled (Table 7). The changes in energy consumption during lockdown in VIC, TAS and NSW are in line with official figures of a 14\% increase in residential consumption in Victoria [4], and a 5\% increase in Europe. The marked effect seasonality on energy use in our sample (relative to the more modest $5 \%$ increase in Europe) may be due in part to the low average levels of thermal performance of legacy Australian housing stock, in which smaller changes in ambient temperature trigger heating/cooling behaviour [36]. Comparison to Europe is difficult, however, given variations in fuel source for space heating, appliance ownership trends [37], variation in lockdown timing and severity [3] and the timing of lockdown in spring (Europe) vs autumn (Australia). There is no evidence in the data of workers shifting their routines to compensate for lack of the commute [8]; however, several participants worked from home or lived close to work (P10, P13, P6, P3, P16), or had family members who continued to work outside of home during lockdown (P1, P11, P15, P19).

Strengers [6] identifies the numerous ways in which householders' daily lives are manifest in electricity consumption data. Our findings provide a snapshot of how COVID-19 lockdown affected life at home for certain households and how these changes affected energy use. Yet our findings also highlight a gap in users' understanding of their energy use. Participants self-reported increased use of appliances, media, and cooking as a result of remaining at home is reflected in the quantitative data for these circuits (Table 8). Yet despite all 17 households having access to detailed energy monitoring, many users substantially under-estimated the effect of air conditioning on their overall energy use. While 11 participants felt their energy use had stayed the same or increased during lockdown, the data shows only four participants' energy use increased and 13 decreased (Table 8). The most conspicuous forms of energy use that most participants reported (e.g., increased laptop, tablet and entertainment use, increased daytime lighting, and reheating lunches) contributed far less in comparison to air conditioning, given the differences in results when seasonality is/is not controlled for (Table $7 \mathrm{a}, \mathrm{b}$ and Table 8). These findings echo those of larger sample size studies which find that outdated models of energy-saving (e.g., 'turn off the lights') persist despite other behaviours causing far greater influence on energy use [29].

Given the substantial effect of seasonality on energy consumption and the tendency for users to under-estimate the amount of energy consumed by air conditioning, the timing of lockdown in Australia has implications for both network demand and users' ability to pay for the energy cost of lockdown. Had lockdown occurred over the hot and humid summer months in Queensland [31], the impact of lockdown on overall energy use may have been far greater. Several participants alluded to this specifically: "Thank goodness lockdown wasn't during summer!" (P12). Modelling of estimated network demand in lockdown conditions during a heat wave would be pertinent for future work to ensure network operators are prepared for such demand events and to inform policy to ensure households are able to afford the increased energy use. As an example, the Queensland Government provided a \$200 COVID utility bill rebate to every household in Queensland, of which \$150 was aimed at covering lockdown-related utility bill expenses [10]. Yet our findings suggest that this rebate may be received by many whose electricity use actually decreased during lockdown relative to their previous bill. On the other hand, if lockdown had occurred over summer, running an air conditioner for an extra eight hours per day on each business day throughout a 40-day lockdown may result in increases in electricity bill costs even greater than $\$ 150$ (Calculation based on: Efficient reverse cycle air conditioner approximately $0.75 \mathrm{~kW} \times \$ 0.28 / \mathrm{kWh} \times 8 \mathrm{~h}$ per day $\times 40$ days $=\$ 67.20$. Inefficient, old, or ducted air conditioner or multiple units, approximately: $3 \mathrm{~kW} \times \$ 0.28 \mathrm{kWh} \times 8 \mathrm{~h} \times 40$ days $=\$ 268$ ). Behind the meter monitoring or a greater incidence of smart metering would allow for more accurate 
measurement of changes in energy use directly attributable to a lockdown event, and hence more accurate calculations of the compensation required by each household, or household type.

\subsection{Engagement with Energy Use Feedback}

Despite all participants having access to detailed energy use feedback, and almost all participants reporting substantial changes to their usage patterns over lockdown, all but three participants accessed their dashboard less during lockdown than prior. The discrepancy between self-reported and actual overall energy use may potentially be symptomatic of this lack of engagement with feedback. Our hypothesis was that lockdown would constitute a salient energy event causing households to re-engage with their data, hence, Hypothesis $\mathbf{2}$ is not supported. This finding may be partly explained in terms of engagement with personal informatics [38] including energy use feedback [21] decreasing naturally over time as users learn the factors affecting a system [21,38]. It is also possible that some participants chose not to access the monitoring if they felt they were using more, for example, research that finds people often choose to remain ignorant of future undesirable outcomes [39]. Yet irrespective of the reason, our findings highlight that ownership of energy monitoring does not guarantee cognizance of energy use, even during periods of increased use.

\subsection{Implications}

At the time of writing (September 2020), COVID-19 is far from over. The state of Victoria continues to endure a prolonged second COVID-19 lockdown due to a second wave of infections [40]. Given the likelihoods of further lockdowns here and elsewhere and the approaching Australian summer, it is vital to rapidly determine how to best inform households how they can manage their energy consumption during lockdown to avoid bill shock and further economic distress. We close with three implications for the provision of information on energy use more generally during COVID-19 lockdown or other lockdown events.

(1) Like others, we argue that access to personal informatics on resource consumption can enable informed energy use decisions [16,27], especially during events (such as COVID-19) which disrupt normal consumption patterns. Yet even with detailed energy monitoring installed, once beyond the initial Discovery phase, households may need prompting to access further information on their energy use. We advocate that providers of energy use feedback (whether electricity network or retail companies, or private suppliers) consider periodic energy use reports or digests to compensate for reduced engagement, as well as specific mechanisms for prompting households to engage with their feedback during significant events (e.g., COVID-19 restrictions).

(2) Householders' misunderstanding of the impact of factors affecting consumption during lockdown has implications for the delivery of information during such events. Our participants accessed their energy use feedback less during lockdown than prior, meaning it is not reasonable to expect householders to seek out this information independently. Accordingly, we advocate mass media advertising which clearly outlines the impact of different appliances on energy use (e.g., cooling and heating vs. laptops, lighting, and entertainment) might improve users' ability to better manage their energy during lockdown. Broadcast media such as TV and radio are found to be one of the most accessed sources of info during disasters [41] and a trusted source of information during the COVID-19 pandemic [42].

(3) Greater visibility of household energy use is vital not only for households, but energy network service providers and governments. Findings from this study suggest the Queensland Government's utility bill assistance package [10] may end up being paid to many households where electricity use decreased relative to their previous (summer) bill. Our data is supplied from private behind-the-meter energy monitoring, yet smart metering penetration is still low in many areas of Australia. With a higher penetration of smart metering networks and governments would be able to better target utility bill assistance and more effectively calculate the compensation required by households during lockdown. 


\subsection{Limitations}

There are limitations inherent in the sample of this study, namely that the smart inverter sample is primarily from urban areas, with regional and remote areas of Australia under-represented. Household size, demographics, and dwelling characteristics are not available from this dataset, hence it is not possible to control for socio-economic status or dwelling type. However, the study uses within-measures analysis and from this dataset seeks to identify trends only.

It should be emphasised that this paper does not attempt to account for all possible factors explaining changes in electricity consumption and we are interested only in estimating the influence of lockdown. Some households may use gas or wood burners for heating or cooking, indicative that electricity is not the only fuel source. There may be a slight influence of lighting on electricity consumption in cooler states between March and June, where the shortening days may lead to greater lighting consumption. However, we have not attempted to control for this, given the dominance of low energy CFL and LED lighting in Australia, the modest latitudes of Australian cities (relative to Europe) and the lack of daylight saving in certain states during lockdown mean that the effect of lighting is expected to be minimal. The per-circuit monitored houses sample is limited by a small sample size and we do not claim to generalise broadly; however, the strength of the sample is the ability for rich qualitative self-reported data to triangulate against aggregate consumption values.

Author Contributions: Conceptualization, S.S.; validation, S.S., R.B., M.G. and N.H.; formal analysis, R.B.; investigation, R.B.; writing—original draft preparation, S.S. and R.B.; writing-review and editing, M.G. and N.H.; All authors have read and agreed to the published version of the manuscript.

Funding: Research for this project was made possible by: Advance Queensland grant number AQPTP01216-17RD1 Redback Smart Monitoring Platform (Advance Queensland Platform Technology Program grant).

Conflicts of Interest: The authors declare no conflict of interest.

\section{References}

1. Liasi, S.G.; Shahbazian, A.; Bina, M.T. COVID-19 Pandemic; Challenges and Opportunities in Power Systems. IEEE Smart Grid 2020, in press.

2. Graff, M.; Carley, S. COVID-19 assistance needs to target energy insecurity. Nat. Energy 2020, 5, 352-354. [CrossRef]

3. Le Quéré, C.; Jackson, R.B.; Jones, M.W.; Smith, A.J.P.; Abernethy, S.; Andrew, R.M.; De-Gol, A.J.; Willis, D.R.; Shan, Y.; Canadell, J.G.; et al. Temporary reduction in daily global $\mathrm{CO}_{2}$ emissions during the COVID-19 forced confinement. Nat. Clim. Chang. 2020, 1-8. [CrossRef]

4. Energy Networks Australia Commercial down v Residential up: COVID-19's Electricity Impact. Available online: https://www.energynetworks.com.au/news/energy-insider/2020-energy-insider/ commercial-down-v-residential-up-covid-19s-electricity-impact/ (accessed on 19 June 2020).

5. DelosDelta The Smart Meter Revolution: How Australia Fell Behind, and How We Can Get Back on Track. Available online: https:/delosdelta.com/wp-content/uploads/2018/10/The-Smart-Meter-Revolution-DelosDelta-Report-FINAL-Oct-2018.pdf (accessed on 5 June 2019).

6. Strengers, Y. Smart Energy Technologies in Everyday Life: Smart Utopia? Palgrave Macmillan: London, UK, 2013.

7. Russell-Bennett, R.; Mulcahy, R.; McAndrew, R.; Letheren, K.; Swinton, T.; Ossington, R.; Horrocks, N. Taking advantage of electricity pricing signals in the digital age: Householders have their say. A summary report. July 2017, pp. 1-98. Available online: https:/energyconsumersaustralia.worldsecuresystems.com/grants/821/ Segmentation-model-for-engaging-consumers-digitally_final-report.pdf. (accessed on 2 October 2020).

8. Australian Energy Market Operator COVID-19 Demand Impact in Australia. Available online: https://aemo.com.au/en/news/demand-impact-australia-covid19 (accessed on 11 July 2020).

9. Anderson, B.; Torriti, J. Explaining shifts in UK electricity demand using time use data from 1974 to 2014. Energy Policy 2018, 123, 544-557. [CrossRef]

10. Queensland Government COVID-19 Household Utility Relief. Available online: https://www.qld.gov. au/community/cost-of-living-support/concessions/energy-concessions/covid-19-household-utility-relief (accessed on 29 June 2020). 
11. Energy Matters Queensland Receives Support through Stimulus Package and Utility Bill Relief. Available online: https://www.energymatters.com.au/renewable-news/queensland-receives-supportthrough-stimulus-package-and-utility-bill-relief/ (accessed on 22 October 2020).

12. Liu, Y.; Nair, N.K.; Renton, A.; Wilson, S. Impact of the Kaikōura earthquake on the electrical power system infrastructure. Bull. N. Z. Soc. Earthq. Eng. 2017, 44, 425-430. [CrossRef]

13. Aloul, F.; Al-Ali, A.R.; Al-Dalky, R.; Al-Mardini, M.; El-Hajj, W. Smart Grid Security: Threats, Vulnerabilities and Solutions. Int. J. Smart Grid Clean Energy 2013. [CrossRef]

14. Nye, M.; Burgess, J. Promoting Durable Change in Household Waste and Energy Use Behaviour; Report prepared for the Department for the Environment; Food and Rural Affairs (DEFRA): UK, 2008. Available online: https://ueaeprints.uea.ac.uk/id/eprint/25463/ (accessed on 20 October 2020).

15. Carrie Armel, K.; Gupta, A.; Shrimali, G.; Albert, A. Is disaggregation the holy grail of energy efficiency? The case of electricity. Energy Policy 2013, 52, 213-234. [CrossRef]

16. Fischer, C. Feedback on household electricity consumption: A tool for saving energy? Energy Effic. 2008, 1, 79-104. [CrossRef]

17. Froehlich, J.; Findlater, L.; Landay, J. The design of eco-feedback technology. In Proceedings of the 28th International Conference on Human Factors in Computing Systems-CHI'10, Atlanta, GA, USA, 10-15 April 2010; ACM: New York, NY, USA, 2010; p. 1999.

18. Darby, S. Smart metering: What potential for householder engagement? Build. Res. Inf. 2010, 38, $442-457$. [CrossRef]

19. Buchanan, K.; Russo, R.; Anderson, B. The question of energy reduction: The problem(s) with feedback. Energy Policy 2015, 77, 89-96. [CrossRef]

20. Australian Energy Regulator My Energy Bill. Available online: https://www.aer.gov.au/consumers/myenergy-bill (accessed on 18 June 2020).

21. Hargreaves, T.; Nye, M.; Burgess, J. Keeping energy visible? Exploring how householders interact with feedback from smart energy monitors in the longer term. Energy Policy 2013, 52, 126-134. [CrossRef]

22. Schwartz, T.; Denef, S.; Stevens, G.; Ramirez, L.; Wulf, V. Cultivating energy literacy-results from a longitudinal living lab study of a home energy management system. In Proceedings of the Conference on Human Factors in Computing Systems, Paris, France, 27 April-2 May 2013.

23. Snow, S.; Viller, S.; Glencross, M.; Horrocks, N. Where Are They Now? Revisiting Energy Use Feedback a Decade after Deployment; Association for Computing Machinery: New York, NY, USA, 2019.

24. Li, I.; Dey, A.K.; Forlizzi, J. Understanding my data, myself. In Proceedings of the 13th International Conference on Ubiquitous Computing-UbiComp'11, Beijing, China, 17-21 September 2011; p. 405.

25. Phisaver Phisaver Energy Monitoring. Available online: www.phisaver.com (accessed on 19 June 2020).

26. Queensland Health Movement and Gathering Direction. Available online: https://www.health.qld.gov.au/ system-governance/legislation/cho-public-health-directions-under-expanded-public-health-act-powers/ movement-gathering-direction (accessed on 22 June 2020).

27. Darby, S. The Effectiveness of Feedback on Energy Consumption: A Review of the Literature on Metering, Billing and Direct Displays; Environmental Change Institute, University of Oxford: Oxford, UK, 2006; Volume 486, p. 26.

28. Swanston, M. Two million plus solar roofs: What's in it for the consumers? Behind Beyond Meter 2020, 381-406. [CrossRef]

29. Lundberg, D.C.; Tang, J.A.; Attari, S.Z. Easy but not effective: Why "turning off the lights" remains a salient energy conserving behaviour in the United States. Energy Res. Soc. Sci. 2019, 58. [CrossRef]

30. Braun, V.; Clarke, V. Using thematic analysis in psychology. Qual. Res. Psychol. 2006, 3, 77-101. [CrossRef]

31. Bureau of Meterology Climate Statistics for Australian Locations: Summary Statistics. Available online: http://www.bom.gov.au/climate/averages (accessed on 18 June 2020).

32. Di Napoli, C.; Pappenberger, F.; Cloke, H.L. Assessing heat-related health risk in Europe via the Universal Thermal Climate Index (UTCI). Int. J. Biometeorol. 2018, 62, 1155-1165. [CrossRef]

33. Kellogg, R.; Wolff, H. Daylight time and energy: Evidence from an Australian experiment. J. Environ. Econ. Manag. 2008, 56, 207-220. [CrossRef]

34. Kipping, A.; Trømborg, E. Modeling hourly consumption of electricity and district heat in non-residential buildings. Energy 2017, 123, 473-486. [CrossRef]

35. Melzi, F.N.; Zayani, M.H.; Hamida, A.B.; Same, A.; Oukhellou, L. Identifying Daily Electric Consumption Patterns from Smart Meter Data by Means of Clustering Algorithms. In Proceedings of the IEEE 14th 
International Conference on Machine Learning and Applications (ICMLA), Orlando, FL, USA, 14-16 December 2006; IEEE: Miami, FL, USA, 2016; pp. 1136-1141.

36. Daniel, L.; Baker, E.; Williamson, T. Cold housing in mild-climate countries: A study of indoor environmental quality and comfort preferences in homes, Adelaide, Australia. Build. Environ. 2019, 151, 207-218. [CrossRef]

37. Hayn, M.; Bertsch, V.; Fichtner, W. Electricity load profiles in Europe: The importance of household segmentation. Energy Res. Soc. Sci. 2014, 3, 30-45. [CrossRef]

38. Li, I.; Dey, A.K.; Forlizzi, J. Understanding my data, myself: Supporting self-reflection with ubicomp technologies. In Proceedings of the UbiComp'11-Proceedings of the 2011 ACM Conference on Ubiquitous Computing, Beijing, China, 17-21 September 2011.

39. Charpentier, C.J.; Bromberg-Martin, E.S.; Sharot, T. Valuation of knowledge and ignorance in mesolimbic reward circuitry. Proc. Natl. Acad. Sci. USA 2018, 115, 7255-7264. [CrossRef] [PubMed]

40. Taylor, J.; Daveys, M. Coronavirus Australia: Melbourne in six-week lockdown after Victoria records 191 new cases. The Guardian, 6 July 2020; 2.

41. Cretikos, M.; Eastwood, K.; Dalton, C.; Merritt, T.; Tuyl, F.; Winn, L.; Durrheim, D. Household disaster preparedness and information sources: Rapid cluster survey after a storm in New South Wales, Australia. BMC Public Health 2008, 8, 1-9. [CrossRef] [PubMed]

42. Bruinen de Bruin, Y.; Lequarre, A.S.; McCourt, J.; Clevestig, P.; Pigazzani, F.; Zare Jeddi, M.; Colosio, C.; Goulart, M. Initial impacts of global risk mitigation measures taken during the combatting of the COVID-19 pandemic. Saf. Sci. 2020, 128, 104773. [CrossRef]

Publisher's Note: MDPI stays neutral with regard to jurisdictional claims in published maps and institutional affiliations.

(C) 2020 by the authors. Licensee MDPI, Basel, Switzerland. This article is an open access article distributed under the terms and conditions of the Creative Commons Attribution (CC BY) license (http://creativecommons.org/licenses/by/4.0/). 